\title{
Localisation of genomic regions controlling microdensitometric parameters of wood characteristics in hybrid larches
}

\author{
Anne Arcade ${ }^{\mathrm{a}, \mathrm{b}}$, Patricia Faivre-Rampant ${ }^{\mathrm{a}, \mathrm{c}}$, Luc E. Pâques ${ }^{\mathrm{a}}$ and Daniel Prat ${ }^{\mathrm{a}, \mathrm{d}^{*}}$ \\ ${ }^{a}$ Unité Amélioration, Génétique et Physiologie Forestières, INRA - Centre d'Orléans, BP 20619, Ardon, 45166 Olivet Cedex, France \\ ${ }^{\mathrm{b}}$ Station de Génétique Végétale, INRA, Ferme du Moulon, 91190 Gif-sur-Yvette, France \\ ${ }^{c}$ Université Henri Poincaré - Nancy I, UMR 1136 Interactions Arbres/Micro-Organismes, BP 239, 54506 Vandœuvre-les-Nancy Cedex, France \\ ${ }^{\mathrm{d}}$ Université Claude Bernard - Lyon 1, UMR 5558 Biométrie et Biologie Évolutive, Bât G. Mendel, 69622 Villeurbanne Cedex, France
}

(Received 5 July 2001; accepted 1 March 2002)

\begin{abstract}
The use of wood quality components in forest trees selection is hampered by long delays before phenotypic evaluation. Marker-assisted selection opens new possibilities since selection becomes feasible even before trait expression. In the present study, we have analysed 224 13-year-old hybrid larches derived from eight progenies from a single female parent in order to localise genomic regions controlling several wood traits. Traits were assessed on radial cores by microdensitometry, a method that provides estimates of wood density and radial growth and avoids tree destruction. Measurements were assessed individually on six consecutive rings. QTL detection was achieved by ANOVA using 68 AFLP markers distributed on average each $20 \mathrm{cM}$ along larch genome. Significant QTLs for at least two out of six studied years are distributed on seven linkage groups. Applications towards marker-assisted selection are discussed.
\end{abstract}

QTL / wood quality / microdensitometry / wood density / Larix

Résumé - Localisation des régions du génome contrôlant des composantes microdensitométriques de la qualité du bois chez des mélèzes hybrides. Les paramètres de qualité du bois sont peu pris en compte dans l'amélioration des arbres forestiers en raison des délais d'évaluation très longs. La sélection assistée par marqueurs ouvre de nouvelles perspectives en rendant possible une sélection précoce pour des caractères à expression tardive. Dans ce travail, nous avons analysé huit descendances de mélèze hybride (Larix decidua $\times$ L. kaempferi) issues d'un même parent et comportant 224 arbres âgés de 13 ans, afin de localiser sur une carte génétique les régions du génome qui contrôlent divers paramètres de qualité du bois. Ces paramètres ont été mesurés sur des carottes de bois par microdensitométrie. Cette méthode permet d'évaluer, de façon non destructrice, de nombreuses composantes de la densité du bois et également de la croissance radiale. Les mesures sont effectuées sur six cernes consécutifs. La localisation des QTL a été menée à l'aide de 68 marqueurs AFLP distants en moyenne de 20 cM et par analyse de variance. Les QTL significatifs pour au moins deux des six années analysées se répartissent sur sept groupes de liaison. Les applications de ces résultats sont discutées essentiellement dans les perspectives de la sélection assistée par marqueurs.

QTL / qualité du bois / microdensitométrie / densité du bois / Larix

\section{INTRODUCTION}

Recent development of molecular markers in forest tree species $[1,3]$ and the subsequent genetic map advent $[4-6$, $13,15,18$ ] open new perspectives in forest tree breeding [12]. Genetic maps provide a tool to locate loci controlling a quantitative trait (QTL). Once QTLs are detected, their effects on the trait phenotypic variation can be estimated. These estimates provide breeders with useful information about ge- netic determinism of the trait: how many loci with strong effects influence the trait, and where they are located within the genome. Correlations between traits can be genetically explained by co-localisation of QTLs. These data are required for marker-assisted selection and they can also be helpful for traditional mass selection.

In forest tree breeding, wood quality would represent one of the most important economic criteria. Unfortunately it is

* Correspondence and reprints

Tel.: 04724329 01; fax: 04788927 19; e-mail: prat@biomserv.univ-lyon1.fr 
generally not included, or only late, in the selection criteria because of the long period required before its confident evaluation. Marker-assisted selection can provide the opportunity to select for a trait even before its expression. This is particularly valuable for forest trees, where the period of time before evaluation of traits expressed in mature individuals is very long. Therefore, marker-assisted selection represents a promising tool for the integration of wood quality as selection criteria in forest tree breeding.

Quality of QTL detection and localisation depends on the accuracy of phenotypic evaluation. Wood specific gravity which is a predictor of several wood mechanical properties can be assessed with great precision with a large piece of wood leading to tree destruction, or with a lower precision by a wood tester called Pilodyn ${ }^{\circledR}$ which avoids tree destruction. Recently, an interesting approach, the wood core microdensitometry, has been developed to provide precise assessment without tree destruction. Different wood quality components can thus be analysed: wood density and ring width of each ring or ring part. Applying this method, accurate QTL detection for wood components becomes possible without tree destruction, as shown in several studies in Pinus taeda $[11,16]$.

QTL detection requires a population of progeny that segregates for both molecular markers and trait values. The lack of inbred lines and multi-generation pedigrees in forest trees can be overcome by taking advantage of their known high level of heterozygosity. Thus the progeny from a controlled cross exhibits enough segregation to be used for genetic map construction [6] and QTL detection [8]. QTLs for wood quality components were thus detected in forest tree species: wood specific gravity was investigated in several species like Pinus radiata [9], P. taeda [8], Eucalyptus grandis [7]. A major QTL for the modulus of elasticity was detected in Cryptomeria japonica [10].

Larch is a timber tree species with a breeding programme, aiming to the production of fast-growing interspecific hybrids (L. decidua $\times$ L. kaempferi) [14]. They usually exhibit a high growth capacity. The integration of wood quality components as selection criteria of parents would increase the value of controlled progenies. Many interspecific controlled crosses are under evaluation in larch. A genetic map is already available in larch [2] and it can be used for QTL localisation. The objectives of the present were to detect, to localise and to estimate the effects of QTLs controlling wood quality components assessed by microdensitometry.

\section{MATERIALS AND METHODS}

\subsection{Plant material}

A European larch (Larix decidua Mill.) tree, (clone no 107 from Sudeten Mountains in Czech Republic) was used as the female parent in controlled crosses with eight Japanese larches (Larix kaempferi (Lamb.) Carr.) used as male parents (table I). Three Japanese larches originated from an artificial stand in Denmark while the five others, selected in provenance trials, originated from four different regions of Japan. The identification of the respective male parent has been kept for all progenies.

Seeds were sown in nursery during spring 1983. Seedlings were then established in a forest trial in spring 1985 at a stand density of 1111 plants ha ${ }^{-1}$. Trees from 53 hybrid families, including the eight studied families, have been randomly distributed into 40 incomplete blocks with a single tree per family and per block. The number of individuals per family ranged from 15 to 38 . The eight studied families accounted for a total of 224 individuals (table I). The forest trial is located at Beaumont-du-Lac (Massif Central, France) at an elevation of about 540 meters. The trial was not yet thinned at the step of core collection.

\subsection{Phenotypic data}

Wood density was first assessed using a Pilodyn (py) on 11-year-old trees. In addition, a diametral wood core was taken from each tree at breast height on 13-year-old trees in the same East to West direction to reduce the variance due to dominant wind effects (from West). The outer edge of the core corresponded to the ring of year 1995. The wood cores were then cut to have a precise and constant thickness $(2.6 \mathrm{~mm})$. Wood strips were finally exposed to homogeneous X-rays in order to obtain a radiograph. The wood density along each core was assessed with a microdensitometer, by means of a continuous scanning of the X-ray radiographs and scored each $24 \mu \mathrm{m}$. Each optical density profile was transformed into a wood specific density profile using a reference wood sample. Eight successive rings could be recorded, but the rings of years 1988 and 1995 were not available for all individuals. Consequently, only six successive rings were further considered.

Each ring was analysed separately. Earlywood and latewood were automatically distinguished within the wood density profile, and their respective densities were then assessed. Values of several components of wood specific gravity were calculated for each ring from years 1989 to 1994 (figure 1): wood specific gravity of the complete ring $(r d)$, earlywood specific gravity $(e d)$, latewood

Table I. Origin of plant material used for QTL detection: European larch clone 107 from Sudeten Mountains was separately pollinated by 8 Japanese larches from Japan or from an artificial stand in Denmark.

\begin{tabular}{|c|c|c|c|c|c|c|c|c|}
\hline \multirow[b]{2}{*}{ Clone } & \multicolumn{8}{|c|}{ Japanese larches } \\
\hline & 3076 & 3078 & 3101 & 3207 & 3211 & 3212 & 3213 & 3217 \\
\hline Provenance & Artificial & Artificial & Artificial & Nishidake & Fuji Mount & Ina & Kamikoshi & Kamikoshi \\
\hline \# Family & 179 & 180 & 181 & 182 & 183 & 184 & 185 & 186 \\
\hline Number of sibs per progeny under test & 35 & 27 & 38 & 29 & 36 & 15 & 23 & 21 \\
\hline
\end{tabular}




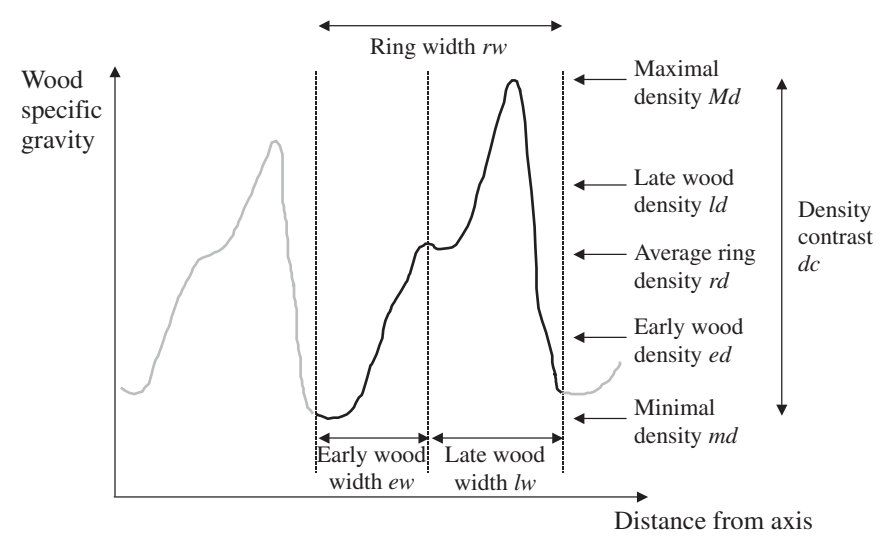

Figure 1. Analysis of a microdensitometric profile from a single ring, with the description of basic parameters assessed.

specific gravity $(l d)$, maximal density of the ring $(M d)$, minimal density of the ring $(m d)$. Two parameters were inferred from these measurements for evaluating wood specific gravity heterogeneity within the ring: the density contrast obtained by the difference between maximal wood specific gravity and minimal wood specific gravity $(d c=M d-m d)$, and the density heterogeneity corresponding to the standard deviation of each individual measurements of wood specific gravity scored each $24 \mu \mathrm{m}$ along the cores $(d h)$.

The same parameters were assessed from the set of all six consecutive rings: the overall wood specific gravity $(R D)$, the average earlywood specific gravity $(E D)$, the average latewood specific gravity across rings $(L D)$, the maximal wood specific gravity of the ring set $(M D)$, and the minimal wood density of the ring set $(m D)$. Wood specific gravity heterogeneity was considered within rings by density contrasts and across rings by density heterogeneity. Two values of density contrast across rings were calculated: $R C$ as the mean value of density contrast of each ring, and $D C$ as the difference between the extreme values of wood specific gravity $(M D-m D)$ observed in the ring set. The wood density heterogeneity across rings was represented by the standard deviation of wood specific gravity of the six consecutive rings $(D H)$ and by the standard deviation among mean density values of each ring $(R H)$.

Radial growth was also analysed: ring width, earlywood width and latewood width could be measured for each ring and for the ring set respectively as $r w, e w, l w, R W, E W$ and $L W$. After estimation of ring diameters on wood cores, total area, earlywood area, and latewood area were calculated for each ring and for the ring set respectively as $r a, e a, l a, R A, E A$ and $L A$.

\subsection{QTL detection}

The female parent was already used for the construction of a genetic map by analysing a larger set of individuals from family 179 [2]. Close markers $(<15 \mathrm{cM})$ were removed for the present study, except when distance between remaining markers could exceed $25 \mathrm{cM}$. Sixty-eight markers were chosen on this genetic map to cover the European larch genome $(2 n=24)$ : 61 markers from the 16 major linkage groups, extending on $888 \mathrm{cM}$ with an average distance of $20.2 \mathrm{cM}$ and seven independent markers. These markers were heterozygous in the common female parent. Markers were obtained and recorded as described by Arcade et al. (2000).
The presence of the marker was checked by the analysis of DNA from each parent. When a male parent showed a fragment with the same size and amplified with the same set of primers than the marker, its progeny was not analysed for that marker. One or more families were deleted for most markers. The genotypes of progenies presented thus too many missing data on consecutive markers of a single linkage group to apply interval mapping. Markers linked to QTLs were therefore detected by analysis of variance. The 68 retained markers were also chosen to keep a minimum of 150 genotyped progenies for each marker after deletion of families without a $1: 1$ segregation.

Analysis of variance was carried out according to the model: $P_{\mathrm{ijk}}=\mu+L_{\mathrm{i}}+M_{\mathrm{j}}+B_{\mathrm{k}}+e_{\mathrm{ijk}}$, where $P_{\mathrm{ijk}}$ represents the phenotypic value of progeny of male parent $j$ growing in block $k$ and showing allele $i$ at marker locus, $\mu$ the mean value for the considered trait of the analysed progenies, $L_{\mathrm{i}}$ the effects of allele $i$ on the phenotypic value, $M_{\mathrm{j}}$ the effect of male parent $j, B_{\mathrm{k}}$ the effect of block $k$ and $e_{\mathrm{ijk}}$ the residual error of phenotypic value of progeny $i j k$. The effects of the genotype at the 68 tested markers on the phenotypic traits are presented.

The proportion of phenotypic variation explained by the marker was defined as the ratio of the sum of squares related to the marker on the sums of squares related to the marker and to the error.

\section{RESULTS}

\subsection{Markers and wood specific gravity}

The partition of wood specific gravity into ring, earlywood and latewood specific gravity for six consecutive rings led to 18 variables. Two independent markers and sixteen markers from eight linkage groups revealed significant effects on most traits for most years (table II). Nevertheless few significant effects were noticed for years 1989, 1992 and 1993. Ring specific gravity appeared to be linked to nine markers, including consecutive markers in linkage groups 1 and 13. Earlywood specific gravity was related to eight markers of which five were located on linkage groups 1 and 2 . Seven markers distributed in five linkage groups showed significant effects on latewood specific gravity. Only one of these markers was also involved in ring specific gravity and another in earlywood specific gravity while four markers were involved in both ring and earlywood specific gravity. In a single year, a maximum of four independent markers were related to a single trait.

The proportion of variation explained by the markers extended from $3.6 \%$ to $5.8 \%$ for ring specific gravity, from $3.6 \%$ to $5.5 \%$ for earlywood specific gravity and from $3.4 \%$ to $6.2 \%$ for latewood specific gravity.

\subsection{Markers and wood specific gravity heterogeneity}

Density contrast $d c$, density heterogeneity $d h$ and contribution of maximal and minimal wood specific gravity were considered. No trait was significantly related to a marker in 1989 (table III). In 1993, only minimal and 
Table II. QTL analysis for wood density assessed from microdensitometric profiles (earlywood, latewood and ring).

\begin{tabular}{|c|c|c|c|c|c|c|c|}
\hline $\begin{array}{c}\text { Linkage }^{\mathrm{a}} \\
\text { Group }\end{array}$ & $\mathbf{c M}^{\mathrm{b}}$ & Marker & Trait $^{c}$ & Year & & $\boldsymbol{F}^{\mathrm{d}}$ & $\begin{array}{c}\% \text { Phenotypic } \\
\text { variance explained } \\
\text { by the marker }\end{array}$ \\
\hline \multirow[t]{15}{*}{1} & 88.0 & AGCctg18 & $e d$ & 1991 & 11.38 & $* *$ & 5.5 \\
\hline & & & $r d$ & 1990 & 7.23 & & 3.6 \\
\hline & & & $r d$ & 1991 & 7.68 & & 3.8 \\
\hline & 107.6 & V17_700 & ed & 1990 & 7.56 & & 3.6 \\
\hline & & & $e d$ & 1991 & 9.76 & $*$ & 4.6 \\
\hline & & & $E D$ & 6 rings & 8.11 & & 3.8 \\
\hline & & & $r d$ & 1990 & 10.85 & $*$ & 5.1 \\
\hline & & & $r d$ & 1991 & 7.12 & & 3.4 \\
\hline & & & $R D$ & 6 rings & 7.26 & & 3.5 \\
\hline & 136.8 & ACGctg8 & $R D$ & 6 rings & 7.21 & & 3.8 \\
\hline & 149.7 & AGGctg12 & $e d$ & 1990 & 7.76 & & 3.9 \\
\hline & & & $l d$ & 1990 & 9.20 & $*$ & 4.6 \\
\hline & & & $L D$ & 6 rings & 7.90 & & 4.1 \\
\hline & & & py & & 8.03 & & 4.0 \\
\hline & 168.0 & AGCcag27 & $l d$ & 1994 & 6.98 & & 3.4 \\
\hline \multirow[t]{4}{*}{2} & 0.0 & AGCcag6 & $r d$ & 1993 & 7.97 & & 3.7 \\
\hline & 59.5 & AE8_1150 & $e d$ & 1992 & 7.28 & & 3.8 \\
\hline & 78.4 & AGCcag14 & $e d$ & 1991 & 8.69 & $*$ & 4.0 \\
\hline & & & ed & 1992 & 7.65 & & 3.6 \\
\hline \multirow[t]{3}{*}{3} & 92.2 & AE8_1400 & $l d$ & 1993 & 9.83 & $*$ & 4.3 \\
\hline & & & $l d$ & 1994 & 14.06 & $* * *$ & 6.2 \\
\hline & 115.1 & AGCcag22 & $l d$ & 1994 & 6.9 & & 3.4 \\
\hline \multirow[t]{4}{*}{5} & 57.5 & AGCctg 15 & $l d$ & 1990 & 9.03 & $*$ & 4.4 \\
\hline & & & $l d$ & 1991 & 9.18 & $*$ & 4.5 \\
\hline & & & $l d$ & 1993 & 7.44 & & 3.7 \\
\hline & & & $r d$ & 1993 & 7.12 & & 3.5 \\
\hline \multirow[t]{2}{*}{6} & 54.6 & AGCcag36 & $e d$ & 1994 & 7.59 & & 4.1 \\
\hline & & & $\mathrm{rd}$ & 1994 & 9.22 & $*$ & 4.9 \\
\hline \multirow[t]{2}{*}{12} & 5.9 & ACGctg5 & py & & 7.71 & & 3.8 \\
\hline & 28.0 & AL20-570 & $l d$ & 1990 & 8.25 & $*$ & 4.7 \\
\hline \multirow[t]{2}{*}{13} & 0.0 & AGCcag12 & $r d$ & 1993 & 9.11 & $*$ & 4.2 \\
\hline & 3.6 & ACCctg6 & $r d$ & 1993 & 7.03 & & 4.5 \\
\hline \multirow[t]{4}{*}{14} & 0.0 & AGCctg24 & $l d$ & 1989 & 9.82 & $*$ & 5.0 \\
\hline & 21.0 & W19_600 & ed & 1989 & 8.11 & & 4.6 \\
\hline & & & $e d$ & 1994 & 8.05 & & 4.2 \\
\hline & & & $r d$ & 1993 & 7.87 & & 4.0 \\
\hline Ind & & P2_650 & $r d$ & 1994 & 11.21 & $*$ & 5.8 \\
\hline Ind & & P2_1050 & $e d$ & 1994 & 10.00 & $*$ & 4.6 \\
\hline
\end{tabular}

a: Ind, independent marker; b: distance to the top marker of the linkage group (according to Arcade et al., 2000); c: according to the text (ed: earlywood density; $l d$ : latewood density; $r d$ : ring density; $p y$ : pilodyn), in capitals: measurement on the six rings set; d: *, $P>0.995$; **, $P>0.999 ; * * *, P>0.9995 ; P>0.99$ otherwise; in bold: QTLs detected for at least two years located on figure 2 .

maximal density showed significant relationships with markers. Six markers from four linkage groups showed significant effects on density contrast. Density heterogeneity was affected by eight markers distributed on five linkage groups. Three markers from three linkage groups were significantly linked to both density contrast and heterogeneity. 
Table III. QTL analyses for extreme wood density and wood density heterogeneity within ring assessed from microdensitometric profiles.

\begin{tabular}{|c|c|c|c|c|c|c|c|}
\hline $\begin{array}{l}\text { Linkage }^{a} \\
\text { Group }\end{array}$ & $\mathbf{c M}^{\mathrm{b}}$ & Marker & Trait $^{c}$ & Year & $F^{\mathrm{d}}$ & & $\begin{array}{l}\% \text { Phenotypic variance } \\
\text { explained by the marker }\end{array}$ \\
\hline \multirow[t]{11}{*}{1} & 71.7 & AGCctg30 & $m d$ & 1992 & 7.07 & & 3.3 \\
\hline & 88.0 & AGCctg18 & $m d$ & 1990 & 7.06 & & 3.5 \\
\hline & 107.6 & V17_700 & $d h$ & 1991 & 6.89 & & 3.3 \\
\hline & & & $m d$ & 1993 & 8.27 & $*$ & 3.9 \\
\hline & 149.7 & AGGctg12 & $M d$ & 1990 & 12.36 & $* *$ & 6.1 \\
\hline & & & Md & 1991 & 11.84 & $*$ & 5.8 \\
\hline & & & $M D$ & 6 rings & 10.01 & $*$ & 5.0 \\
\hline & 168.0 & AGCcag27 & $d c$ & 1994 & 13.70 & $* * *$ & 6.4 \\
\hline & & & $d h$ & 1994 & 8.01 & & 3.9 \\
\hline & & & $M d$ & 1994 & 7.95 & & 3.8 \\
\hline & 250.6 & AGGctg13 & $d h$ & 1994 & 7.57 & & 3.7 \\
\hline \multirow[t]{5}{*}{2} & 59.5 & AE8_1150 & $m d$ & 1992 & 10.44 & $*$ & 5.4 \\
\hline & 78.4 & AGCcag14 & $m d$ & 1991 & 15.28 & $* * *$ & 6.8 \\
\hline & & & $m d$ & 1992 & 9.51 & $*$ & 4.4 \\
\hline & 131.5 & V17_900 & $D C$ & 6 rings & 9.02 & $*$ & 4.3 \\
\hline & 164.4 & A10_630 & $D C$ & 6 rings & 6.98 & & 3.3 \\
\hline \multirow[t]{10}{*}{3} & 69.3 & AGCcag16 & $d c$ & 1992 & 7.68 & & 3.6 \\
\hline & & & $R C$ & 6 rings & 7.45 & & 4.0 \\
\hline & 92.2 & AE8_1400 & $d c$ & 1992 & 11.11 & $*$ & 4.8 \\
\hline & & & $d c$ & 1994 & 13.99 & $* * *$ & 6.2 \\
\hline & & & $D C$ & 6 rings & 8.33 & $*$ & 4.4 \\
\hline & & & $d h$ & 1994 & 10.02 & $*$ & 4.5 \\
\hline & & & Md & 1992 & 9.62 & $*$ & 4.2 \\
\hline & & & $M d$ & 1993 & 9.27 & $*$ & 4.1 \\
\hline & & & Md & 1994 & 11.82 & $* *$ & 5.3 \\
\hline & & & $R C$ & 6 rings & 8.75 & $*$ & 4.6 \\
\hline \multirow[t]{12}{*}{5} & 36.0 & V18_540 & $d c$ & 1991 & 12.76 & $* * *$ & 6.1 \\
\hline & & & $d h$ & 1992 & 8.65 & $*$ & 4.2 \\
\hline & & & $d h$ & 1994 & 9.74 & $*$ & 4.8 \\
\hline & & & $M d$ & 1991 & 9.40 & $*$ & 4.5 \\
\hline & & & $\boldsymbol{R H}$ & 6 rings & 7.84 & & 6.1 \\
\hline & 57.5 & AGCctg15 & $d c$ & 1990 & 10.95 & $*$ & 8.3 \\
\hline & & & $d c$ & 1991 & 9.71 & $*$ & 4.7 \\
\hline & & & Md & 1990 & 12.93 & $* * *$ & 6.2 \\
\hline & & & Md & 1991 & 14.73 & $* * *$ & 7.0 \\
\hline & & & Md & 1992 & 7.62 & & 3.8 \\
\hline & & & Md & 1993 & 11.00 & $*$ & 5.3 \\
\hline & & & $M D$ & 6 rings & 7.65 & & 4.1 \\
\hline \multirow[t]{3}{*}{6} & 26.8 & ACCctg 5 & $d h$ & 1990 & 8.86 & $*$ & 4.2 \\
\hline & 54.6 & AGCcag36 & $m d$ & 1994 & 7.83 & & 4.2 \\
\hline & 68.0 & AGCctg26 & $d h$ & 1990 & 13.02 & $* * *$ & 6.1 \\
\hline 8 & 0.0 & AGCctg32 & $d h$ & 1991 & 8.61 & $*$ & 4.6 \\
\hline \multirow[t]{3}{*}{9} & 0.0 & AGCctg 4 & DH & 6 rings & 7.25 & & 3.9 \\
\hline & & & $R C$ & 6 rings & 7.10 & & 3.8 \\
\hline & & & $\boldsymbol{R H}$ & 6 rings & 11.70 & $* *$ & 3.8 \\
\hline \multirow[t]{2}{*}{12} & 28.0 & AL20_570 & $d c$ & 1990 & 14.79 & $* * *$ & 8.2 \\
\hline & & & $\mathrm{Md}$ & 1990 & 13.93 & $* * *$ & 7.7 \\
\hline \multirow[t]{2}{*}{ Ind } & & V17_950 & $d h$ & 1994 & 8.71 & $*$ & 4.3 \\
\hline & & & $\mathrm{Md}$ & 1994 & 7.15 & & 3.5 \\
\hline
\end{tabular}

a, b, d, *,**, ***: see comments below table II; c: according to the text ( $m d$ : minimal density; $M d$ : maximal density; $d c$ : density contrast; $d h$ : density heterogeneity; $R C$ : ring contrast; $R H$ : ring heterogeneity), in capitals: measurement on the six rings set. 
Table IV. QTL analyses for radial growth assessed from microdensitometric profiles.

\begin{tabular}{|c|c|c|c|c|c|c|c|}
\hline $\begin{array}{l}\text { Linkage }^{\mathrm{a}} \\
\text { Group }\end{array}$ & $\mathbf{c M}^{\mathrm{b}}$ & Marker & Trait $^{\mathrm{c}}$ & Year & $F^{\mathrm{d}}$ & & $\begin{array}{c}\% \text { Phenotypic } \\
\text { variance explained } \\
\text { by the marker }\end{array}$ \\
\hline \multirow[t]{12}{*}{1} & 136.8 & ACGctg8 & ra & 1992 & 7.53 & & 3.8 \\
\hline & 197.8 & ACGctg12 & $e a$ & 1990 & 12.02 & $* *$ & 5.7 \\
\hline & & & $l a$ & 1990 & 9.09 & $*$ & 4.4 \\
\hline & & & $l a$ & 1991 & 9.27 & $*$ & 4.4 \\
\hline & & & $l a$ & 1992 & 7.13 & & 3.4 \\
\hline & & & ra & 1990 & 11.67 & $* *$ & 5.6 \\
\hline & 214.9 & ACGctg20 & $e a$ & 1989 & 8.64 & $*$ & 4.6 \\
\hline & & & $e a$ & 1990 & 9.45 & $*$ & 4.6 \\
\hline & & & ew & 1991 & 8.82 & $*$ & 4.3 \\
\hline & & & la & 1991 & 7.47 & & 3.7 \\
\hline & & & $r a$ & 1989 & 9.66 & $*$ & 5.1 \\
\hline & & & $r a$ & 1990 & 8.51 & $*$ & 4.2 \\
\hline 2 & 59.5 & AE8_1150 & $l w$ & 1992 & 7.27 & & 3.8 \\
\hline \multirow[t]{6}{*}{5} & 36.0 & V18_540 & $e a$ & 1989 & 8.18 & & 4.4 \\
\hline & & & $e a$ & 1990 & 8.71 & $*$ & 4.3 \\
\hline & & & $e a$ & 1991 & 7.00 & & 3.4 \\
\hline & & & la & 1990 & 8.80 & $*$ & 4.3 \\
\hline & & & $r a$ & 1989 & 7.20 & & 3.9 \\
\hline & & & $r a$ & 1990 & 9.29 & $*$ & 4.5 \\
\hline 6 & 28.6 & ACCctg5 & la & 1991 & 7.26 & & 3.4 \\
\hline \multirow[t]{7}{*}{7} & 0.0 & AGCcag 13 & la & 1993 & 7.76 & & 3.6 \\
\hline & & & $r a$ & 1993 & 7.04 & & 3.3 \\
\hline & & & $r a$ & 1994 & 7.25 & & 3.5 \\
\hline & 18.4 & AGGctg10 & la & 1993 & 8.62 & $*$ & 4.1 \\
\hline & 36.2 & AH1_1200 & $e a$ & 1992 & 8.37 & $*$ & 5.1 \\
\hline & & & la & 1991 & 7.73 & & 4.8 \\
\hline & & & ra & 1992 & 7.03 & & 4.3 \\
\hline 10 & 19.8 & AGCcag8 & ra & 1993 & 6.92 & & 3.3 \\
\hline 13 & 0.0 & AGCcag12 & $l w$ & 1991 & 8.91 & $*$ & 4.1 \\
\hline 14 & 0.0 & AGCctg24 & $r w$ & 1994 & 7.49 & & 3.6 \\
\hline \multirow[t]{15}{*}{ Ind } & & E6_800 & $e a$ & 1989 & 8.89 & $*$ & 5.0 \\
\hline & & & $e a$ & 1990 & 8.33 & $*$ & 4.3 \\
\hline & & & $e a$ & 1991 & 7.44 & & 3.9 \\
\hline & & & $e a$ & 1992 & 11.07 & $*$ & 5.7 \\
\hline & & & $e a$ & 1993 & 11.56 & $* *$ & 5.9 \\
\hline & & & $e a$ & 1994 & 7.44 & & 4.0 \\
\hline & & & $E A$ & 6 rings & 16.37 & $* * *$ & 8.2 \\
\hline & & & ew & 1989 & 10.15 & $*$ & 5.7 \\
\hline & & & $E W$ & 6 rings & 8.27 & $*$ & 4.3 \\
\hline & & & $r a$ & 1990 & 9.40 & $*$ & 4.9 \\
\hline & & & $r a$ & 1991 & 14.17 & $* * *$ & 7.1 \\
\hline & & & $r a$ & 1992 & 10.40 & $*$ & 5.4 \\
\hline & & & $r a$ & 1993 & 7.93 & & 4.1 \\
\hline & & & $R A$ & 6 rings & 13.03 & $* * *$ & 6.6 \\
\hline & & & $r w$ & 1989 & 6.95 & & 4.0 \\
\hline Ind & & P2_650 & $l w$ & 1989 & 7.25 & & 4.0 \\
\hline
\end{tabular}

$\mathrm{a}, \mathrm{b}, \mathrm{d},{ }^{*}, * *, * * *$ : see comments below table II; c: according to the text (ea: earlywood area; la: latewood area; $r a$ : ring area; $e w$ : earlywood width; $l w$ : latewood width; $r w$ : ring width), in capitals: measurement on the six rings set. 
Maximal wood specific gravity was related to seven markers distributed in five linkage groups. Six markers from three linkage groups affected minimal wood specific gravity. No single marker was related to both minimal and maximal wood specific gravity.

Only one marker showed significant effects on minimal wood specific gravity and density heterogeneity while six markers from five linkage groups were significantly linked to maximal wood specific gravity and to density contrast or density heterogeneity in the same year.

Markers explained from $3.3 \%$ to $6.8 \%$ of phenotypical variation for minimal wood specific gravity and from $3.5 \%$ to $7.7 \%$ of variation for maximal wood specific gravity. The phenotypical variation explained by markers for density contrast was higher, from $3.6 \%$ to $8.3 \%$, while it was lower for density heterogeneity, from $3.3 \%$ to $6.1 \%$.

\subsection{Markers and radial growth}

Few significant effects were detected on the ring, earlywood or latewood width, however they did affect ring, earlywood and latewood area (table IV). Two markers from two linkage groups affected both ring and earlywood width. Eight markers from five linkage groups affected significantly ring area. Five of these markers, distributed on four linkage groups affected also earlywood area for the same years.

Latewood area was affected by seven markers distributed in four linkage groups, but only for four out of the six studied years. Four markers from three linkage groups affected ring, earlywood and latewood area. One unlinked marker (E6_800) showed significant effects for several consecutive years.

Markers explained less than $8 \%$ of phenotypical variation: from $3.3 \%$ to $7.1 \%$ for ring area, from $3.4 \%$ to $5.7 \%$ for earlywood area and from $3.4 \%$ to $4.8 \%$ for latewood area.

\subsection{QTL stability across years}

Most of the significant effects described above were only observed for a single year. Few markers showed significant effects during several years (figure 2). Ring specific gravity and earlywood specific gravity were controlled by a common marker (V17_700) for two consecutive years. This marker showed also significant effects on the mean values $E D$ and $R D$ assessed for the six consecutive years (figure 2). Other

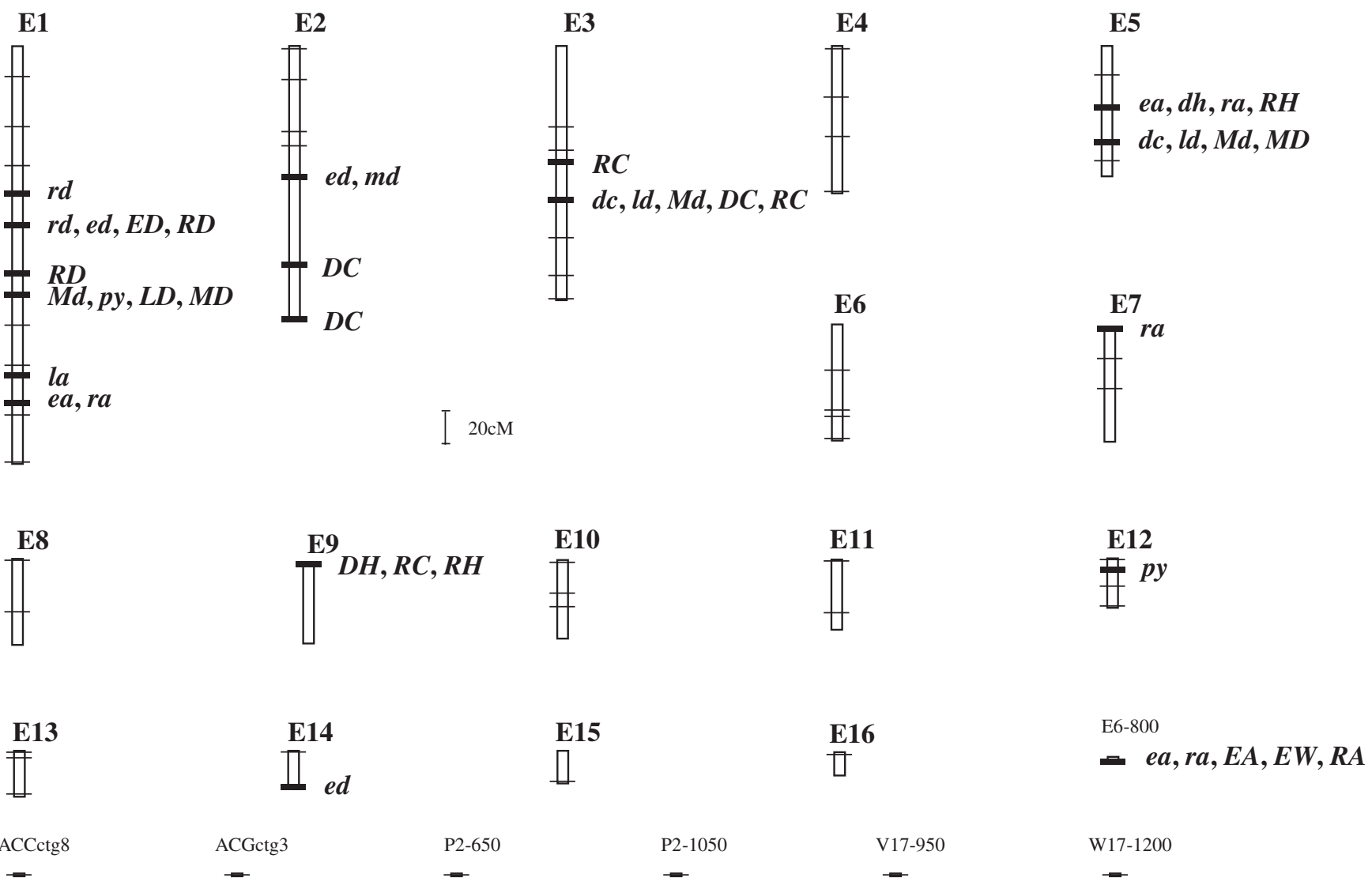

Figure 2. Localisation of markers significantly linked to a QTL for at least two years for the same trait, or to a QTL for trait assessed on the ring set; E1 to E16: linkage groups of the European larch female parent. Position of each marker tested for QTL detection is mentioned on the map. Independent markers are included in the figure. 
markers affecting earlywood or latewood specific gravity for at least two years were not detected by the analysis of the mean values from the six consecutive rings.

Three markers affected maximal wood specific gravity for two to four consecutive years, two of these markers affected also the mean value $M D$ of the six consecutive rings (figure 2). Two markers significantly affected density contrast for two years: marker located in linkage group five was significant for years 1990 and 1991, while marker located in linkage group 3 was significant for years 1992 and 1994.

Markers ACGctg20 and V18_540 from linkage groups 1 and 5 affected ring and earlywood area in 1989 and 1990, an independent marker, E6_800 affected the same traits for at least four consecutive years. This is the only marker showing a significant effect for the complete analysed period. The mean values $R A$ and $E A$ of the six rings were also significantly affected by this marker. This marker also affected the mean value of earlywood width for the six analysed rings, but it was significant for only one year.

\section{DISCUSSION}

One of the problems encountered in QTL detection deals with the threshold of statistical tests. Numerous tests are often carried out (more than 6256 in the present study) leading to numerous false positive QTL results. In the present study, about 62 false positive QTLs were expected at the threshold $\alpha=0.01$. The application of a more selective threshold increases the risk of no detection of a QTL. In the present study, we have considered that a marker is linked to a QTL when the same marker is significant for the same trait for at least two years, in order to reduce the proportion of false positive QTLs (figure 2). This removed most stochastic significant tests. Correlations between phenotypic traits of successive years may also distort analyses leading to biased number and localisation of QTLs. Moreover only steady-over-time QTLs may be involved in marker-assisted selection for wood quality. QTLs specific to only one year, even highly significant, may not have a biological meaning since they could be detected just by chance.

The phenotypic variation explained by the QTL varies greatly across traits and studies, even within wood components: it reaches about $45 \%$ for the modulus of elasticity [10], and it stays around $10 \%$ for wood density in Pinus taeda [16] or Eucalyptus grandis [7, 19]. In the present study, the maximum phenotypic variability related to the marker is about $8 \%$. Traits analysed in this study have a genetic component and their heritabilities ranged mostly between 0.1 and 0.6 (Pâques et al., in preparation). The phenotypic variation explained by the markers remained lower than the heritability values assessed at the trait level. Thus the variation of markers did not represent a negligible part of genetic variation for the traits. Marker-assisted selection applied on one or few markers may take advantage of the major part of genetic variation of the trait.

Few QTLs were detected for ring width while several with larger effects were detected for ring, earlywood and latewood areas. Area parameters are more related to the wood volume produced and to its resource allocation.

Several wood components are controlled by the same genomic region since they appeared related to a single common marker. Several regions were involved in the control of density heterogeneity in larch; most of them were also involved in maximal wood specific gravity, suggesting a contribution of maximal density-to-density variation. Earlywood specific gravity or radial growth have a high contribution to ring specific gravity or growth, as several common markers are revealed. Few markers controlling both earlywood and latewood specific gravity or growth were detected; their expression appeared different. In Pinus taeda, many loci appeared to be involved in the control of earlywood and latewood specific gravity, but few were also common [16]. In this latter study, most QTLs were detected for only a single ring; nevertheless some QTLs were more time-stable. Stability of QTL expression over time depends on the considered QTL. Environmental conditions and seasonal effects may greatly influence their expression.

As we have noted, QTL detection has been investigated in several studies, but the application in marker-aided selection requires further analyses. The relationships between markers and loci controlling the trait should be precisely established in the breeding population prior to the use of markers as early selection criteria. Most QTLs have been detected in a single family and their occurrence in other families is not sure because of segregations for different loci. We need to have results from various families to assess the polymorphism of QTL and to use markers for selection in breeding populations. On the other hand, markers linked to QTLs will not be sufficient for most applications. Only selection on polymorphic genes involved in the traits will provide genetic gains from breeding population. Genetic mapping with genes of known function [17] and the test of their possible co-localisation with QTLs should be investigated. Comparative genome mapping will also allow to suspect QTLs in some genomic regions from results obtained in other species [17]. Marker-assisted selection efficiency will be further tested in forest tree species.

Acknowledgements: Authors are grateful to Philippe Rozenberg for his help in microdensitometric analysis of wood cores, and to everyone participating in measurements and management of the larch field trial. This study was financially supported by the European Union grant No FAIR CT3354 ('LARCH' project).

\section{REFERENCES}

[1] Adams W.T., Strauss S.H., Copes D.L., Griffin A.R., Population genetics of forest trees, Kluwer Academic Publishers, Dordrecht, 1992. 
[2] Arcade A., Anselin F., Faivre-Rampant P., Lesage M.C., Pâques L.E., Prat D., Application of AFLP, RAPD and ISSR markers to genetic mapping of European larch and Japanese larch, Theor. Appl. Genet. 100 (2000) 299-307.

[3] Baradat P., Adams W.T., Müller-Starck G., Population genetics and genetic conservation of forest trees, SPB Academic Publishing, Amsterdam, 1995.

[4] Bradshaw H.D., Villar M., Watson B.D., Otto K.G., Stewart S., Stettler R.F., Molecular genetics of growth and development in Populus. III: A genetic linkage map of a hybrid poplar composed of RFLP, STS and RAPD markers, Theor. Appl. Genet. 89 (1994) 167-178.

[5] Chagné D., Lalanne C., Madur D., Kumar S., Frigerio J.M., Krier C., Decroocq S., Savouré A., Bou-Dagher-Karrat M., Bertocchi E., Brach J., Plomion C., A high density genetic map of maritime pine based on AFLPs, Ann. For. Sci. 59 (2002) 627-636.

[6] Grattapaglia D., Sederoff R., Genetic linkage maps of Eucalyptus grandis and Eucalyptus urophylla using a pseudo-testcross: mapping strategy and RAPD markers, Genetics 137 (1994) 1121-1137.

[7] Grattapaglia D., Bertolucci F.L.G., Penchel R., Sederoff R.R., Genetic mapping of quantitative trait loci controlling growth and wood quality traits in Eucalyptus grandis using a maternal half-sib family and RAPD markers, Genetics 144 (1996) 1205-1214.

[8] Groover A., Devey M., Fiddler T., Lee J., Megraw R., Mitchell-Olds T., Sherman B., Vujcic S., Williams C., Neale D., Identification of quantitative trait loci influencing wood specific gravity in an outbred pedigree of loblolly pine, Genetics 138 (1994) 1293-1300.

[9] Kumar S., Spelman R.J., Garrick D.J., Richardson T.E., Lausberg M., Wilcox P.L., Multiple-marker mapping of wood density loci in an outbred pedigree of radiata pine, Theor. Appl. Genet. 100 (2000) 926-933.

[10] Kuramoto N., Kondo T., Fujisawa Y., Nakata R., Hayashi E., Goto Y., Detection of quantitative trait loci for wood strength in Cryptomeria japonica, Can. J. For. Res. 30 (2000) 1525-1533.
[11] Neale D.B., Sewell M.M., Brown G.R., Molecular dissection of the quantitative inheritance of wood property traits in loblolly pine, Ann. For. Sci. 59 (2002) 595-605.

[12] Neale D.B., Williams C.G., Restriction fragment length polymorphism mapping in conifers and applications to forest genetics and tree improvement, Can. J. For. Res. 21 (1991) 545-554.

[13] Paglia G.P., Olivieri A.M., Morgante M., Towards second-generation STS (sequence-tagged sites) linkage maps in conifers: a genetic map of Norway spruce (Picea abies K), Mol. Gen. Genet. 258 (1998) 466-478.

[14] Pâques L.E, A critical review of larch hybridization and its incidence on breeding strategies, Ann. Sci. For. 46 (1989) 141-153.

[15] Plomion C., O’Malley D.M., Durel C.E., Genomic analysis in maritime pine (Pinus pinaster): comparison of two RAPD maps using selfed and open-pollinated seeds of the same individual, Theor. Appl. Genet. 90 (1995) $1028-1034$.

[16] Sewell M.M., Bassoni D.L., Megraw R.A., Wheeler N.C., Neale D.B., Identification of QTLs influencing wood property traits in loblolly pine (Pinus taeda L.), Theor. Appl. Genet. 101 (2000) 1273-1281.

[17] Temesgen B., Brown G.R., Harry D.E., Kinlaw C.S., Sewell M.M., Neale D.B., Genetic mapping of expressed sequence tag polymorphism (ESTP) markers in loblolly pine (Pinus taeda L.), Theor. Appl. Genet. 102 (2001) 664-675.

[18] Tulsieram L.K., Glaubitz J.C., Kiss G., Carlson J.E., Single tree genetic linkage mapping in conifers using haploid DNA from megagametophytes, Biotechnology 10 (1992) 686-690.

[19] Verhaegen D., Plomion C., Gion J.M., Poitel M., Costa P., Kremer A., Quantitative trait dissection analysis in Eucalyptus using RAPD markers, Theor. Appl. Genet. 95 (1997) 597-608.

To access this journal online: www.edpsciences.org 
